\title{
Peculiarities of Decarbonization Strategies of the Largest Players in the Oil and Gas Industry: Similarities and Differences
}

\author{
Anastasia Masalkova $^{1, *}$, Elena Romanova ${ }^{2}$ \\ ${ }^{1}$ Gubkin University, Faculty of International Energy Business, Moscow, Russia \\ ${ }^{2}$ National Research University Higher School of Economics, Faculty of World Economy and International Affairs, \\ Moscow, Russia \\ "Corresponding author.Email: starkova_anastas@mail.ru
}

\begin{abstract}
The activities of companies in the oil and gas sector have a significant impact on climate change. Fighting the greenhouse gas emissions growth is at the heart of energy decarbonization. Despite the prevailing importance of fossil fuels, one of the most promising scenarios for development of world energy is the transition to renewable energy sources. The decarbonization strategy for the oil and gas industry includes a wide range of economic and technological measures. Nevertheless, there are significant differences in the environmental policy of oil and gas companies depending on the chosen strategic vector of development. Due to the above, it is necessary to offer a classification of oil and gas companies by the type of decarbonization, which allows making effective management decisions.
\end{abstract}

Keywords: decarbonization, renewable, energy, company.

\section{INTRODUCTION}

The study work is devoted to the issue of decarbonization strategies of the largest oil and gas companies at the present stage. Currently, the problem of global climate change is attracting close attention of scientists and the public, and the concept of sustainable development reflects the main challenges of the 21st century. The global climate challenge threatens food security, increases the risk of environmental disasters, and contributes to conflicts due to malnutrition and unregulated migration flows. The energy sector accounts for more than two thirds of global greenhouse gas emissions [1]. In view of the foregoing, the future of the energy sector is associated with the development of renewable energy sources and the introduction of green technologies at various stages of the production process [33]. Despite the fact that the transition to a sustainable energy system is possible with the support of state regulators, investors and end users, the central role is assigned to oil and gas companies, which determine the strategic vector of energy development. The competitiveness of companies correlates with the chosen strategic model of growth and development. The strategic priorities of oil and gas companies have evolved under the influence of external factors. During the first, second and third energy transitions, the strategic choices of companies coincided with expansionary interests and vertical integration policies. Despite the fact that the concept of dominance of hydrocarbons still does not recede into the background, the fourth energy transition stimulates decarbonization processes. In view of the insufficient adaptability of companies to the new requirements and conditions of the oil and gas industry development, the revision and approval of new strategic plans focused on decarbonization of the energy sector is of key importance. Therefore, the issues of diversifying the activities of oil and gas companies and determining the similarities and differences in the strategies of the leaders of the oil and gas industry are studied in this work in the context of the transformation of the world energy market.

The object of the study is the process of achieving carbon neutrality by oil and gas companies.

The subject of the study is the similarities and differences of decarbonization strategies of the largest oil and gas companies.

The aim of the study is to study the features that characterize the process of transition of oil and gas companies to the decarbonization strategy and to 
determine the similarities and differences in the environmental policies of the largest oil and gas companies.

To achieve this goal, the following tasks were solved:

1) To analyze the key indicators that form the basis of decarbonization of the oil and gas industry.

2) To offer a classification of decarbonization strategies for the largest oil and gas companies.

The theoretical basis of this study was the various fundamental studies of domestic and foreign authors on the energy transition and changes in the strategic priorities of oil and gas companies.

The scientific and methodological concept of energy transition was offered by Vaclav Smil [2]. Later, this idea was developed in the study of D. Hauff, describing the energy transition as a structural change in the global energy system in the long run [3]. Bongsuk Sung and Sang-Do Park emphasize the importance of the social nature of the energy transition [4]. In some papers of foreign authors, the economic aspect of the transition to a low-carbon economy is given the most importance [5].

There are a number of works by domestic researchers that consider the fundamental principles and evolution of the strategic development of companies in the oil and gas industry. These questions are provided in the papers of I.V. Andronova, A.G. Aganbegyan, V.A. Kryukova, A.E. Cherepovitsyna, V.F. Dunaev [6].

In his work A.A. Konoplyanik considers the problems of strategic management of the oil and gas complex at the stage of decarbonization of the energy sector [7].

In the paper of Christophe McGlade and Paul Ekins reflects the risks of the fourth energy transition, influencing the activities of large oil and gas companies [8].
An in-depth and comprehensive consideration of various aspects of strategic positioning is contained in the paper of M. Zhong, which examines the process of forming a new strategy for oil and gas companies focused on investments in renewable energy sources [9]. Analytical reports of the consulting company Wood Mackenzie are devoted to the analysis of the prospects for development of alternative energy [10]. The authors of the paper argue that diversification of the asset portfolio through development of renewable energy sources is the most significant strategic change in the activities of oil and gas companies. Attention is also paid to the role of solar and wind energy in ensuring the reliability and sustainability of the power system. Finally, the report of the analytical center Chatham House criticizes the existing strategic model of large oil and gas companies and notes the need for innovative development [11].

Despite the multifaceted and extensive study that determines the role of oil and gas companies in the context of decarbonization, the perfection of the strategic planning mechanism requires additional consideration [34].

\section{MATERIALS AND METHODS}

The research information base was compiled by the international ratings of Forbes, Statista, Brand Finance, annual reports and official statistical data of the companies considered in the study, data of the international agencies IEA, IRENA. Herein, the general

Table 1. Key indicators and ratios of 10 large oil and gas companies.

\begin{tabular}{|c|c|c|c|c|c|c|}
\hline Company & Country & $\begin{array}{c}\text { Volume of } \\
\text { Sales* }\end{array}$ & Profit* & Assets* & $\begin{array}{c}\text { Market } \\
\text { price* }\end{array}$ & $\begin{array}{c}\text { Return on Investment } \\
\text { (ROIC) } \%\end{array}$ \\
\hline $\begin{array}{c}\text { Saudi } \\
\text { Aramco }\end{array}$ & Saudi Arabia & 329.8 & 88.1 & 398.3 & $1,684.8$ & 27 \\
\hline BP & $\begin{array}{c}\text { United } \\
\text { Kingdom }\end{array}$ & 296.97 & 4.0 & 295.194 & 119.1 & 2 \\
\hline ExxonMobil & USA & 256 & 14.3 & 362.6 & 196.6 & 6 \\
\hline Shell & Netherlands & 311.6 & 15.8 & 394 & 126.5 & 6 \\
\hline TotalEnergies & France & 176.2 & 11.3 & 273.3 & 93.1 & 6 \\
\hline Gazprom & Russia & 122.6 & 22.7 & 331.7 & 60.8 & \\
\hline PetroChina & China & 364.1 & 6.5 & 392.3 & 65.9 & \\
\hline Sinopec & China & 418.77 & 8.1 & 254.8 & 76.6 & \\
\hline Chevron & USA & 140.1 & 2.9 & 237.4 & 171.8 & 5 \\
\hline Petrobras & Brazil & 78.9 & 10.2 & 230.2 & 43.5 & 5 \\
\hline
\end{tabular}

Note - * USD billion.

Source: Compiled by the author based on company reports [15-24] 
Table 2. Results of compliance of the existing strategy of companies with the global climate agenda.

\begin{tabular}{|c|c|c|c|c|c|c|c|c|c|}
\hline Company/Question Number & $\mathbf{1}$ & $\mathbf{2}$ & $\mathbf{3}$ & $\mathbf{4}$ & $\mathbf{5}$ & $\mathbf{6}$ & $\mathbf{7}$ & $\mathbf{8}$ & $\mathbf{9}$ \\
\hline Saudi Aramco & 1 & 1 & 1 & 0 & 0 & 0 & 1 & 0 & 0 \\
\hline BP & 1 & 1 & 1 & 1 & 1 & 1 & 1 & 1 & 1 \\
\hline ExxonMobil & 1 & 1 & 1 & 1 & 1 & 1 & 1 & 0 & 0 \\
\hline Shell & 1 & 1 & 1 & 0 & 1 & 1 & 1 & 1 & 1 \\
\hline TotalEnergies & 1 & 1 & 1 & 1 & 1 & 1 & 1 & 1 & 1 \\
\hline Gazprom & 1 & 1 & 1 & 0 & 1 & 1 & 1 & 0 & 0 \\
\hline PetroChina & 1 & 1 & 0 & 0 & 1 & 1 & 0 & 0 & 0 \\
\hline Sinopec & 1 & 1 & 0 & 0 & 1 & 1 & 0 & 0 & 0 \\
\hline Chevron & 1 & 1 & 1 & 0 & 1 & 1 & 1 & 1 & 1 \\
\hline Petrobras & 1 & 1 & 1 & 1 & 1 & 1 & 1 & 1 & 1 \\
\hline
\end{tabular}

Note: Headings 1-9 correspond to questions in order

Source: compiled by the author based on company reports [15-24]

scientific methods were used: analysis, synthesis, analogy, comparative method and classification.

For comparative analysis, 10 large oil and gas companies were identified according to Forbes ratings "Global 2000 The World's Largest Public Companies" [12], Statista "2020 ranking of the leading global oil and gas companies based on revenue" [13], Brand Finance "Oil\&Gas 50 2020" [14]: Saudi Arabian Oil Company (Saudi Aramco), BP Public Limited Company (BP), ExxonMobil Corporation (ExxonMobil), Royal Dutch Shell Public Limited Company (Shell), TotalEnergies SE (TotalEnergies), Public Joint Stock Company Gazprom (Gazprom), PetroChina Company Limited (PetroChina), China Petroleum \& Chemical Corporation (Sinopec), Chevron Corporation (Chevron), Petróleo Brasileiro S.A. (Petrobras). Table 1 presents the key indicators and ratios that were used to compile the above ratings.

\section{RESULTS AND DISCUSSION}

Comparative analysis of decarbonization strategies is based on the following parameters: compliance of the company's existing strategy with the global climate agenda, share of investments in renewable energy sources in total capital expenditures (Capex), development of certain areas of alternative energy, investments in carbon capture technologies, development of venture capital investments, change in the share of natural gas in the company's production structure, reducing methane emissions, investing in the creation and maintenance of a sustainable transport infrastructure, as well as improving energy efficiency, as well as the sale of oil and gas assets.

Compliance with the existing strategy of the company with the global climate agenda is determined by the set goals and the set of actions taken by the company in response to global climate change. This parameter is linked to the emission management policies of Scope 1, 2 and 3, which indicates the overriding importance of the parameter in the decarbonization sector. To assess the first parameter, the following questions were provided (Table 2).

1. Does the company consider global climate change to be a significant threat and/or a unique business opportunity?

2. Is the company committed to fighting the climate changes?

3. Does the company support the efforts of national and international communities in promoting climate change mitigation?

4. Does the company consider risks and new opportunities in its strategy?

5. Does the company manage climate risk?

Table 3. The share of investments of oil and gas companies in low-carbon energy of total capital costs.

\begin{tabular}{|c|c|c|}
\hline Company & CAPEX & Share of investments in RES from CAPEX $* *$ \\
\hline Saudi Aramco & 35 & 0.02 \\
\hline BP & 14.1 & 2.3 \\
\hline ExxonMobil & 23 & 0.22 \\
\hline Shell & 16.6 & 1.33 \\
\hline TotalEnergies & 15.6 & 4.3 \\
\hline Gazprom & 21.4 & 0.01 \\
\hline PetroChina & 45.6 & 0.01 \\
\hline Sinopec & 20.8 & 0.21 \\
\hline Chevron & 14 & 0.23 \\
\hline Petrobras & 10 & 0.7 \\
\hline
\end{tabular}

Note - * USD billion, ** percent

Source: compiled by the author based on company reports [15-24] 
6. Has the company set targets to reduce greenhouse gas emissions?

7. Has the company's data on greenhouse gas emissions reductions in Scope 1 and 2 been verified?

8. Does the company report on Scope 3 emission reductions?

9. Has the company introduced an internal carbon price?

Companies were rated by scale from 0 to 1 , where 0 means negative response and 1 means positive response.

The data presented in Table 2 allow us to analyze the attitude of the selected large oil and gas companies to the climate problem. Note that BP, Total Energies and Petrobras are the absolute climate leaders. Shell and Chevron are highly ranked, however, the risks and new opportunities associated with climate change have not been reflected in the companies' strategies. ExxonMobil and Gazprom are successfully implementing their Scope 1 and 2 emission reduction strategies; however, they face difficulties in reporting on Scope 3 emissions management. Another distinguishing feature of Gazprom and ExxonMobil is the lack of information on the domestic carbon price. Saudi Aramco, PetroChina and Sinopec show the least interest in the climate agenda. At the heart of their climate strategy is awareness of the business implications of climate change. It shall be noted that PetroChina and Sinopec have set targets for reducing greenhouse gas emissions, which indicates the prospects for reducing Scope 3 emissions in the future.

Despite the fact that the definition of the company's climate goals plays a fundamental role in decarbonizing the oil and gas sector, the parameters considered in the model allow differentiating the approaches of oil and gas companies to portfolio diversification.

Oil and gas companies can apply for the status of energy companies, subject to an increase in the share of renewable energy sources. This direction has become widespread among super majors, however, the contribution of oil and gas companies to renewable energy sources differs significantly depending on the chosen strategy. Table 3 presents the results of a comparison of the share of investments in RES in total capital expenditures.

The data allows us to assess the efforts of oil and gas companies to ensure the development of a low-carbon economy. Also, the share of investments in renewable energy sources indicates the achieved degree of decarbonization of oil and gas companies. It can be noted that Total Energies, BP and Shell hold leading positions in alternative energy investments despite the relatively low indicators of total capital expenditures.

In addition to analyzing the ratio of the share of investments in renewable energy sources and capital costs, it is important to identify the main directions of development of renewable energy inherent in each individual oil and gas company (Table 4).

In order to identify low-carbon leaders, the following directions of the RES sector were considered: hydrogen, solar, wind, bio, hydro and geothermal energy. The scale used was from 0 to 1 , where 0 means a negative answer and 1 means a positive answer. Based on the results of Table 4, it shall be emphasized that the most profitable and interesting industries for oil and gas companies are solar and wind energy. Total Energies has achieved the highest results in the development of solar and wind energy. Currently, the total installed capacity of RES of Total Energies is 7,000 MW. The company is pursuing ambitious goals to expand its RES portfolio. The installed capacity is expected to reach $100 \mathrm{GW}$ in 2050 [25]. BP and Shell are direct competitors to Total Energies in the development of "new renewable energy sources." BP's new strategy implies the need to revise the company's priorities in favor of alternative energy in order to most effectively move from the category of international oil companies to the category of integrated energy companies. The efforts of oil and gas companies Saudi Aramco and Gazprom to develop solar energy are of great importance. Despite the predominant share of hydrocarbon sources, Saudi Aramco is engaged in the construction of solar and wind power plants to meet

Table 4. Renewable energy development activities of oil and gas companies.

\begin{tabular}{|c|c|c|c|c|c|c|c|}
\hline \multirow{2}{*}{ Company } & Hydrogen & Sunny & Wind & Bio- & Hydro- & Geothermal \\
\cline { 2 - 7 } & \multicolumn{7}{|c|}{ Energy } \\
\hline Saudi Aramco & 0 & 1 & 1 & 0 & 0 & 0 \\
\hline BP & 0 & 1 & 1 & 1 & 0 & 0 \\
\hline ExxonMobil & 1 & 0 & 0 & 1 & 0 & 0 \\
\hline Shell & 1 & 1 & 1 & 1 & 0 & 0 \\
\hline Total Energies & 1 & 1 & 1 & 1 & 1 & 0 \\
\hline Gazprom & 0 & 1 & 0 & 0 & 0 & 1 \\
\hline PetroChina & 1 & 1 & 1 & 1 & 0 & 1 \\
\hline Sinopec & 1 & 1 & 1 & 1 & 0 & 1 \\
\hline Chevron & 1 & 1 & 1 & 1 & 0 & 1 \\
\hline Petrobras & 1 & 1 & 1 & 0 & 1 & 0 \\
\hline
\end{tabular}

Source: compiled by the author based on company reports [15-24] 
Table 5. Qualitative parameters of decarbonization and diversification of oil and gas companies.

\begin{tabular}{|c|c|c|c|c|c|c|c|}
\hline Company & $\mathbf{1}$ & $\mathbf{2}$ & $\mathbf{3}$ & $\mathbf{4}$ & $\mathbf{5}$ & $\mathbf{6}$ & $\mathbf{7}$ \\
\hline Saudi Aramco & 1 & 1 & 1 & 1 & 1 & 1 & 1 \\
\hline BP & 1 & 1 & 1 & 1 & 1 & 1 & 1 \\
\hline ExxonMobil & 1 & 0 & 1 & 1 & 1 & 1 & 1 \\
\hline Shell & 1 & 1 & 1 & 1 & 1 & 1 & 1 \\
\hline TotalEnergies & 0 & 1 & 1 & 1 & 1 & 1 & 1 \\
\hline Gazprom & 0 & 0 & 1 & 1 & 1 & 0 & 0 \\
\hline PetroChina & 1 & 1 & 1 & 1 & 0 & 0 & 1 \\
\hline Sinopec & 0 & 1 & 1 & 1 & 1 & 0 & 1 \\
\hline Chevron & 1 & 1 & 1 & 1 & 1 & 1 & 1 \\
\hline Petrobras & 0 & 0 & 1 & 1 & 1 & 0 & 1 \\
\hline
\end{tabular}

Note - Headings

1 - Investments in carbon storage and capture technologies

2 - Development of green and sustainable transport infrastructure

3 - Increase in the share of natural gas

4 - Reducing methane emissions

5 - Improving energy efficiency

6 - Venture funding for startups

7 - Sale of oil and gas assets

Source: compiled by the author based on company reports [15-24]

domestic demand, as well as the subsequent export of solar energy to European countries [26]. Gazprom is showing a growing interest in solar and geothermal energy. One of Gazprom's pilot projects was the construction of solar power plants at an oil refinery [15]. ExxonMobil is the most conservative position based on hydrocarbon sources. Over the past decade, ExxonMobil has invested over USD 250 million in bioenergy, however, the main focus of the company has become the decarbonization of oil and gas activities and the reduction of greenhouse gas emissions [27]. A feature of Petrobras' renewable energy portfolio is the growing investment in hydropower. Sinopec's renewable energy strategy stands out among Chinese oil and gas companies. Currently, the company is the largest supplier of geothermal energy in the world, implements a number of large-scale projects in the field of biofuel production, increases investment in solar energy [18].

Finally, it is pertinent to draw attention to a comparison of decarbonization parameters that allow assessing the efforts of oil and gas companies to improve energy efficiency, support innovative enterprises and increase the share of "green" fossil fuels (Table 5).

The scale used was from 0 to 1 , where 0 means a negative answer and 1 means a positive answer. Seven indicators were considered in the table: investments in carbon storage and capture technologies, development of green and sustainable transport infrastructure, increasing the share of natural gas, reducing methane emissions, improving energy efficiency, venture financing for startups, selling oil and gas assets.

The analysis carried out indicates that climate goals can be achieved through the application of an integrated approach to solving the problems of the fourth energy transition. For example, ExxonMobil is way below to BP,
Shell, TotalEnergies and Chevron in the development of renewable energy, however, it demonstrates a commitment to reducing greenhouse gas emissions, implements carbon capture technologies, and also actively partners with technology start-ups to find new solutions to meet growing energy demand in the face of declining greenhouse gas emissions [27]. Venture funding for startups has become one of the key areas of development for Saudi Aramco, BP, Shell and TotalEnergies [17]. Saudi Aramco has created a corporate venture fund for the implementation of digital technologies and the implementation of promising projects in the field of sustainable development and alternative energy [17]. As part of the issue under study, it shall be noted that a number of oil and gas companies are taking over startups and mature companies in the electricity market. In 2016, Shell bought one of the largest charging networks, New Motion [28]. Also in 2018, TotalEnergies acquired electricity company Direct Energie and charger supplier G2Mobility. [29] The parameter of increasing natural gas is present in every strategy of the considered oil and gas companies. Despite a number of restrictions and risks, ExxonMobil, TotalEnergies and Chevron are investing in large LNG projects. In turn, the activities of the Chinese oil and gas companies Sinopec and PetroChina are focused on the development of charging infrastructure for electric vehicles. Along with the reduction of greenhouse gas emissions, the central issue of decarbonization of the oil and gas sector is the sale of oil and gas assets. Massive sale of super majors' assets reaches USD 110 billion [30]. Some companies like BP, TotalEnergies, Chevron are planning to sell oil and gas assets to finance promising renewable energy projects [31]. 


\section{CONCLUSION}

So, the comparative analysis helped us to draw relevant conclusions about the similarities and differences in decarbonization strategies of large oil and gas companies.

1) Studying the approaches of Saudi Aramco, BP, ExxonMobil, Shell, TotalEnergies, Gazprom, PetroChina, Sinopec, Chevron, Petrobras to the transformation of the oil and gas sector allows us to make sure that decarbonization is the basis for achieving carbon neutrality. The effectiveness of the environmental strategy of oil and gas companies is determined by the following indicators: integration of the foundations of the global climate story, a growing share of investments in renewable energy sources of total capital expenditures, portfolio diversification and the development of alternative energy, investments in carbon storage and capture technologies, investments in the development of environmentally friendly and sustainable transport infrastructure, increasing the share of natural gas, reducing methane emissions, improving energy efficiency, venture financing for startups to improve green technologies, partial sale of oil and gas assets. These components determine the level of readiness of oil and gas companies for the global decarbonization process.

2) The transformation process of oil and gas companies includes the decarbonization of the oil and gas industry and the diversification of the oil and gas industry. ExxonMobil, Gazprom, PetroChina and Saudi Aramco form a segment of companies engaged in active decarbonization of oil and gas activities. This group of companies is characterized by a significant reduction in greenhouse gas emissions, an increase in the share of natural gas, a lack of significant investments in renewable energy sources, the consistent implementation of carbon capture technologies, and an increase in energy efficiency. PetroChina's hallmark is the lowest share of investment in renewable energy at the highest total capital expenditure. Sinopec, Chevron, Petrobras belong to the middle segment. These companies pay their attention to both the development of renewable energy and the improvement of energy efficiency in the oil and gas industry. The volume of investments in RES is moderate and sufficient for a consistent portfolio restructuring. Therefore, it shall be emphasized that Sinopec, Chevron and Petrobras are companies that are mainly implementing a strategy for decarbonizing oil and gas activities. However, they have great potential to stimulate the development of alternative energy. To move into the next category of leading companies, Sinopec needs to meet the climate requirements for reducing emissions in areas 1, 2, 3. Finally, TotalEnergies, BP, Shell are leaders in the diversification of oil and gas activities. The activities of oil and gas companies are characterized by active investment in research and development in the field of renewable energy sources. The difference between these companies and their competitors lies in their relatively narrow specialization. Despite the provision of comprehensive support for innovative projects, the promotion of the concept of sustainable development at all stages of the value chain, the listed companies have identified the key priorities of the diversification strategy. TotalEnergies and BP are actively developing solar and wind energy. One of the dominant directions of BP and Shell is the creation of a green transportation system, the quantitative increase and the qualitative improvement of charging stations for electric vehicles.

\section{REFERENCES}

[1] Achieving Zero with Renewable Energy: Reducing $\mathrm{CO} 2$ emissions from industry and transport in line with a climate target of $1.5 \circ \mathrm{C}$ : IRENA, 2020. https://www.irena.org/publications.

[2] V. Smil, Research of energy transitions: a dozen of insights based on performance. Energy Research and Social Sciences 22 (2016) pp. 194-196. https://www.sciencedirect.com/science/article/pii/S 2214629616302006.

[3] Climate Emergency, Urban Opportunities: Global Report 2019. https://urbantransitions.global/en/pub lication/climate-emergency-urban-opportunity.

[4] B. Sun, Who is driving the transition to a renewable energy economy? Multilateral perspective of social innovation. Sustainable development 10(2) (2018) pp. 488 495. https://www.mdpi.com/2071 1050/10/ $2 / 448$.

[5] M. Rushel, T. Mlynarsky, A. Shurley, Transition to energy policy - perspectives of different states. Institute for Energy Policy Ignacy Lukasiewicz 2017 p. 308.

[6] Yu.K. Shafranik, Oil and Gas Sector of Russia: A Difficult Path to Diversity, 2016 p. 272.

[7] A.A. Konoplyanik, Oil market: from cartelization to cooperation? "Oil and Gas Vertical" 9(10) (2020) pp. $80-91$.

[8] E.S. Hanley, The role of hydrogen in the future of low-carbon energy - a review of existing. Reviews of Renewable and Sustainable Energy 82(3) (2018) pp. 3027-3045. https://www.sciencedirect.com/sci ence/article/pii/S1364032117314089.

[9] M. Zhong, Contours of energy transition: investments of international oil and gas companies in renewable energy sources. Electricity 31(1) (2018) pp. 82 - 91.https://www.sciencedirect.com/s cience/article/pii/S1040619017303561. 
[10] Could renewables be the next big thing for big companies? Summary. Wood Mackenzie is a Verisk company, 2017. https://www.woodmac.com/report s/upstream-oil-and-gas-could-renewables-be-themajors-next-big-thing-46827370/.

[11] International oil companies. The Death of the Old Business Model: A Study. - Text: electronic. Royal Institute of International Relations Chatham House, 2016. https://www.chathamhouse.org/2016/05/inter national-oil-companies-death-old-business-model.

[12] List: 2021 GLOBAL 2000. The largest public companies in the world, 2021. https://www.forbes.com/lists/global2000/\#54e0a27 $5 \mathrm{ac} 04$.

[13] Statista: Database, Hamburg, Germany, 2007. https://www.statista.com/.

[14] Oil and Gas 50: Annual report of the most valuable and strongest oil and gas brands. Brand Finance, 2021. https://brandirectory.com/download - report/ brand-finance-oil-and-gas-50-2021-preview.pdf.

[15] Gazprom. https://www.gazprom-neft.ru/.

[16] Exxon Mobil Corporation. https://corporate.exxon mobil.com/.

[17] Saudi Aramco Energy Ventures LLC. https://saev.com/.

[18] China Petrochemical Corporation (Sinopec Group. http://www.sinopec.com/.

[19] TotalEnergies. https://www.total.

[20] BP. https://www.bp.com/.

[21] Shell. https://www.shell.com.ru/.

[22] Chevron Corporation. https://www.chevron.com/.

[23] Petrobras. https://petrobras.com.br/en/.

[24] PetroChina Company Limited. http://www.petrochi na.com.cn/ptr/.

[25] V. Sidorovich, Decarbonization of the oil and gas industry of the third category. ReNen: electronic journal. https://renen.ru/dekarbonizatsiya - neftegaz ovoj-otrasli-tretej-kategorii/.

[26] Saudi Arabia is increasing the capacity of alternative energy. TASS: Russian state news agency of the federal level, 2017. https://tass.ru/plusone/4046603

[27] ExxonMobil is looking for some good startups. Energy factor Exxonmobil. https://energyfactor.exx onmobil.com/energy-innovation/rd/scouting-forstartups/.
[28] E-Mobility Review Report: The Future of Electric Vehicle Implementation, 2020. https://newmotion.c om/en.

[29] French Total completes Direct Energie deal and acquires electric car charging firm. Reuters. https://www.reuters.com/article/us-totaldeals/frances-total-completes-direct-energie-dealand-buys-electric-vehicles-charging-firmidUSKCN1M016W.

[30] M. Kutuzova, Eight large oil and gas companies sell assets worth \$ 110 billion. Oil Capital: electronic journal. https://oilcapital.ru/news/companies/20-042021/vosem-neftegazovyh-meydzhorovrasprodayut-aktivy-na-110-milliardov-dollarov.

[31] Rystad Energy: Major company sales could be $\$ 27$ billion. The Oil \& Gas Journal: electronic journal. https://www.ogj.com/generalinterest/article/14072215/rystad-energy-majorsglobal-selling-spree-could-fetch-27-billion.

[32] M. Rico, G. Benito, A. R. Salgueiro, A. DiezHerrero, J. G. Pereira, Journal of Hazardous Materials 2 p. 200.

[33] E.V. Maksimova, V.V. Morozov. Modern challenges for the oil and gas sector and adaptation to them. In journal "Problems of Economics and Management of the Oil and Gas Complex", 6 (2021), pp.5-9.

[34] E.V. Maksimova, V.V. Morozov, M. Krasyuk. The role of the oil and gas sector in the country's economic development. In scientific and economic journal "Problems of Economics and Management of the Oil and Gas Complex", 9 (2020), pp.17-20. 